\title{
ANÁlise de CRescimento de Brachiaria brizantha Submetida A DOSES REDUZIDAS DE FlUAZIFOP-P-BUTIL ${ }^{1}$
}

\author{
Growth analysis of Brachiaria brizantha Under Reduced Rates of Fluazifop-p-butyl \\ SILVA, A.C. ${ }^{2}$, FERREIRA, L.R. ${ }^{3}$, SILVA, A.A. ${ }^{4}$ e FERREIRA, F.A. ${ }^{5}$
}

\begin{abstract}
RESUMO - Objetivou-se neste trabalho avaliar o crescimento de Brachiaria brizantha cv. MG5 submetida a doses reduzidas de fluazifop-p-butil, visando a viabilização do consórcio desta espécie com a soja. Os efeitos de três doses do herbicida $\left(0,18,75\right.$ e $\left.37,50 \mathrm{~g} \mathrm{ha}^{-1}\right)$ sobre o crescimento de $B$. brizantha foram avaliados em oito épocas $(14,18,28,35,42,49,56$ e 70 dias após a emergência - DAE). O delineamento experimental utilizado foi o inteiramente casualizado, com quatro repetições. Em cada época de avaliação fez-se a coleta das plantas e a determinação da área foliar e da biomassa seca de folhas, colmos e raízes. Com base nesses dados, foram determinadas a taxa de crescimento absoluto e relativo, a taxa de assimilação líquida, a razão de área foliar, a área foliar específica e a razão de biomassa dos colmos e das folhas. Observou-se que doses reduzidas do fluazifop-p-butil promoveram a quebra da dominância apical de $B$. brizantha, induzindo acentuado perfilhamento. Nessa condição, verificou-se ainda aumento da participação dos colmos na biomassa seca total e redução do comprimento dos colmos em relação ao tratamento sem herbicida. Além disso, as plantas tratadas com fluazifop-p-butil apresentaram folhas mais finas, com redução de área foliar e da taxa de crescimento absoluto, demonstrando a possibilidade da utilização de doses reduzidas de fluazifop-p-butil somente para reduzir o crescimento de B. brizantha.
\end{abstract}

Palavras-chave: análise de crescimento, braquiária, herbicida, ACCase, integração agricultura-pecuária.

\begin{abstract}
The objective of this work was to evaluate Brachiaria brizantha cv. MG5 growth under reduced rates of fluazifop-p-butyl to allow its intercropping with soybean. The effects of three doses of the herbicide $\left(0,18,75\right.$ and $\left.37.50 \mathrm{~g} \mathrm{ha}^{-1}\right)$ on $\mathbf{B}$. brizantha growth were evaluated in eight timings $(14,18,28,35,42,49,56$ and 70 days after emergence-DAE). The experiment was arranged in a completely randomized design, with four replications. At each timing, the plants were harvested and the biomass of the leaves, stem, roots and leaf area was obtained. Absolute growth rate, relative growth rate, net assimilation rate, leaf area ratio, specific leaf area, stem and leaf weight ratio were calculated using dry biomass and leaf area data. B. brizantha had suppressed the apical dominance by reduced rates of fluazifop-p-butyl inducing greater tillering. The stems presented greater total biomass and stem length was reduced in the plants treated with the herbicide. The plants treated with fluazifop-p-butyl had thinner leaves, reduced leaf area and absolute growth rate, showing that it is possible to use reduced doses of fluazifop-p-butyl only to reduce $\boldsymbol{B}$. brizantha growth.
\end{abstract}

Key words: growth analysis, Brachiaria, herbicide, ACCase, crop-livestock integration.

Recebido para publicação em 29.10.2004 e na forma revisada em 21.4.2005.

2 Pós-graduanda do curso de Doutorado em Fitotecnia da Universidade Federal de Viçosa - UFV, 36571-000 Viçosa-MG, <andreia@vicosa.ufv.br>; ${ }^{3}$ Prof. Adjunto do Dep. de Fitotecnia da UFV, <lroberto@ufv.br>; ${ }^{4}$ Prof. Adjunto do Dep. de Fitotecnia da UFV, < aasilva@ufv.br>; ${ }^{5}$ Prof. Titular do Dep. de Fitotecnia da UFV, <faffonso@ufv.br>. 


\section{INTRODUÇÃO}

Os herbicidas inibidores da acetil coenzima A carboxilase (ACCase) são utilizados em pós-emergência, principalmente em culturas dicotiledôneas, para o controle de gramíneas anuais e perenes. Plantas sob a ação desses produtos têm a biossintese de lipídios bloqueada (Konishi et al., 1996) e, em conseqüência disso, ocorre a paralisação do crescimento das raízes e da parte aérea e a alteração da pigmentação das folhas, iniciando processo necrótico nas regiões meristemáticas, que se espalha por toda a planta (Thill \& Weller, 1995).

Tem-se observado a possibilidade de redução da dose recomendada de inibidores da ACCase, mantendo-se controle satisfatório de algumas gramineas infestantes, sem prejuizo na produção das culturas (Lima \& MachadoNeto, 2001; Timossi \& Durigan, 2002). Além de permitir o controle de gramíneas com menor custo, o uso de doses reduzidas de herbicidas graminicidas pode permitir o consórcio de espécies gramíneas com culturas leguminosas, como a soja. Essa técnica é de grande importância na implantação do sistema integrado agricultura-pecuária (Silva et al., 2004).

$B$. brizantha vem se destacando como excelente forrageira, produzindo grande quantidade de biomassa de boa qualidade, sendo uma das espécies mais empregadas em sistemas de consórcio com culturas anuais (Perez et al., 1993; Duarte et al., 1995; Portes et al., 2000; Jakelaitis et al., 2004). Entretanto, a análise de crescimento de gramíneas forrageiras tropicais tem recebido pouca atenção da pesquisa, sendo escassas as estimativas de parâmetros como área foliar específica, razão de peso foliar, razão de área foliar, taxa assimilatória líquida e taxa de crescimento relativo (Gomide, 1997). O estudo dessas características é uma ferramenta importante para se estabelecer o manejo de $B$. brizantha em diferentes sistemas produtivos, pois fornece subsídios para o entendimento das respostas morfológicas e fisiológicas desta espécie em diversas situações de cultivo (Portes et al., 2000; Dias-filho \& Carvalho, 2000; Dias-Filho, 2000).

Neste trabalho, objetivou-se analisar o crescimento de $B$. brizantha cv. MG5 submetida a doses reduzidas de fluazifop-p-butil, herbicida inibidor da ACCase, visando a viabilização do consórcio desta espécie com soja.

\section{MATERIAL E MÉTODOS}

O experimento foi conduzido no período de fevereiro a maio de 2003, em casa de vegetação, na Universidade Federal de Viçosa (UFV). As temperaturas máxima e mínima e a umidade relativa do ar no interior da casa de vegetação durante o período de condução do ensaio são apresentadas na Figura 1.

Cada unidade experimental foi composta por um vaso contendo duas plantas de $B$. brizantha cv. MG5, as quais cresceram em vasos com 3,0 L de substrato (Argissolo Vermelho-Amarelo câmbico, acrescido de $4 \mathrm{~kg} \mathrm{~m}^{-3}$ do fertilizante 4-14-8).

O delineamento experimental adotado foi o inteiramente casualizado, com quatro repetições, seguindo o arranjo fatorial $8 \times 3$, sendo oito épocas de coleta das plantas (14, $18,28,35,42,49,56$ e 70 dias após a emergência - DAE) e três manejos (sem herbicida, 18,75 e $37,50 \mathrm{~g} \mathrm{ha}^{-1}$ de fluazifop-p-butil). As doses do herbicida corresponderam a $10 \%$ e $20 \%$ da dose média recomendada para a cultura da soja.

Na aplicação do herbicida, feita aos 28 DAE de $B$. brizantha, utilizou-se pulverizador costal de precisão, pressurizado com $\mathrm{CO}_{2}$ e equipado com dois bicos TT110.02, espaçados de 0,5 m, aplicando-se o equivalente a $200 \mathrm{~L} \mathrm{ha}^{-1}$ de calda.

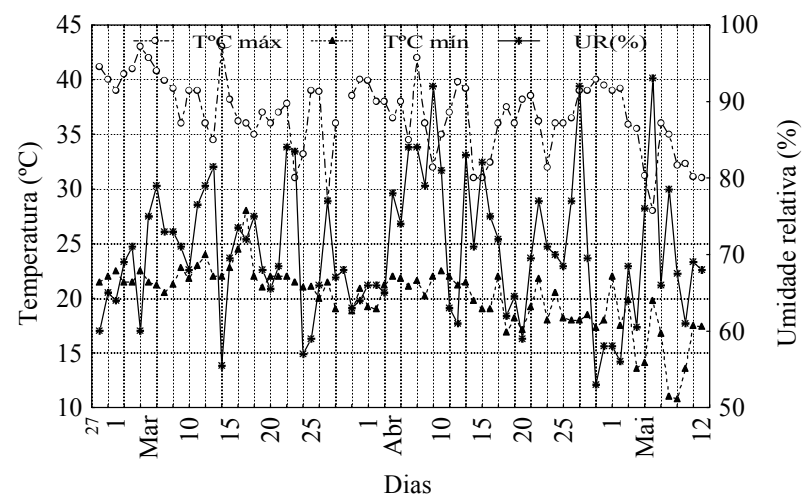

Figura 1 - Dados de temperaturas máxima $\left(\mathrm{T}^{\circ} \mathrm{C}\right.$ máx $)$ e mínima ( $\mathrm{T}^{\circ} \mathrm{C}$ mín) e umidade relativa do ar (UR\%), no interior da casa de vegetação, referentes ao período de condução do ensaio. 
Por ocasião das coletas, as plantas de $B$. brizantha foram desmembradas em folhas, colmos e raízes. Os colmos foram medidos e contados. A biomassa seca foi obtida após secagem do material em estufa de circulação forçada de ar a $70^{\circ} \mathrm{C} \pm 2^{\circ} \mathrm{C}$, onde o material permaneceu até atingir peso constante. A área foliar das plantas foi determinada utilizando-se um medidor de área foliar $\mathrm{Li}$-cor, modelo LI-3100.

Com base nesses dados, foram determinadas a taxa de crescimento absoluto [TCA $=\left(\mathrm{P}_{2}-\mathrm{P}_{1}\right) /\left(\mathrm{t}_{2}-\mathrm{t}_{1}\right)$, em que $\mathrm{P}_{2}$ e $\mathrm{P}_{1}$ são as biomassas secas de duas amostragens sucessivas e $t_{2}$ e $t_{1}$ são os dias decorridos entre as duas observações]; taxa de crescimento relativo $\left[\mathrm{TCR}=\left(\mathrm{LnP}_{2}-\mathrm{LnP}_{1}\right) /\left(\mathrm{t}_{2}-\mathrm{t}_{1}\right)\right]$; taxa de assimilação líquida $\left[\mathrm{TAL}=\left[\left(\mathrm{P}_{2}-\mathrm{P}_{1}\right) /\right.\right.$ $\left.\left.\left(t_{2}-t_{1}\right)\right]^{*}\left[\operatorname{Ln} A_{2}-\operatorname{Ln} A_{1}\right) /\left(A_{2}-A_{1}\right)\right]$, em que $A_{2}$ e $A_{1}$ são as áreas foliares de duas amostragens consecutivas]; razão de área foliar [RAF = (área foliar/biomassa total)]; área foliar específica $[\mathrm{AFE}=$ (área foliar/biomassa das folhas)]; razão de biomassa dos colmos [RBC = (biomassa de colmos/biomassa total)]; e razão de biomassa das folhas $[\mathrm{RBF}=$ (biomassa das folhas $/$ biomassa total)] (Benincasa, 2003).

Todos os dados foram submetidos à análise de variância, e os modelos de regressão foram escolhidos com base na significância dos coeficientes de regressão, no coeficiente de determinação e no fenômeno em estudo.

\section{RESULTADOS E DISCUSSÃO}

Constatou-se interação entre manejos e épocas de coleta para a biomassa seca total (Figura 2-A) e biomassa seca de folhas (Figura 2-B), colmos (Figura 2-C) e raízes (Figura 2-D) de B. brizantha.
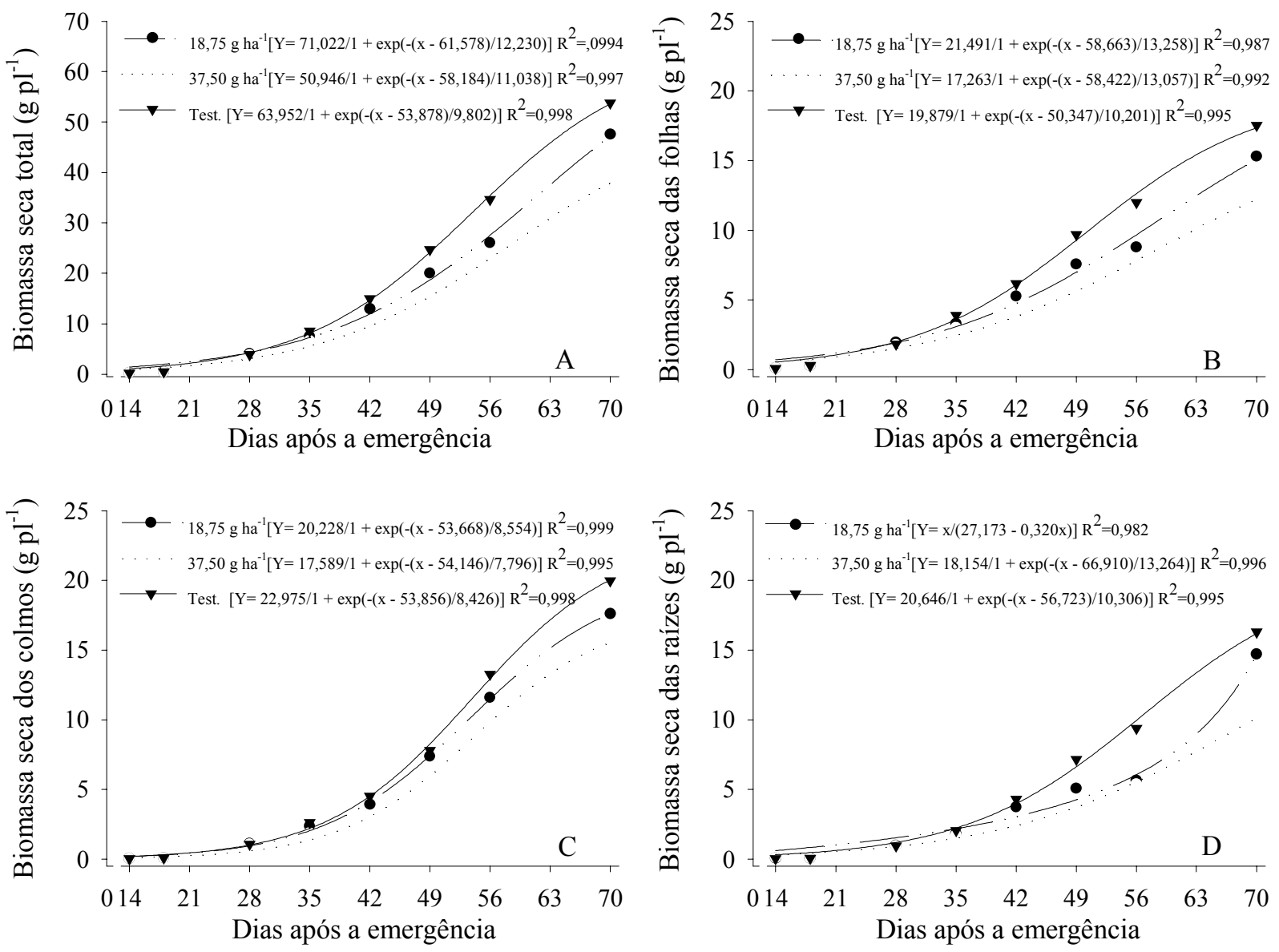

Figura 2 - Biomassa seca total (A) e biomassa seca das folhas (B), dos colmos (C) e das raízes (D) de plantas de B. brizantha, em função da época de avaliação e de doses de fluazifop-p-butil. 
Observou-se que, a partir de 28 DAE (data da aplicação do fluazifop-p-butil), houve redução no crescimento de $B$. brizantha sob efeito do herbicida, sendo este mais evidente quando se aplicou a maior dose $\left(37,5 \mathrm{~g} \mathrm{ha}^{-1}\right)$. Considerando que houve redução, mas não supressão, do acúmulo de biomassa, é provável que as doses reduzidas do herbicida tenham inibido parcial ou temporariamente a enzima ACCase e, conseqüentemente, a síntese de lipídios. Resultados semelhantes foram também observados para o acúmulo de biomassa de folhas (Figura 2-B), colmos (Figura 2-C) e raizes (Figura 2-D), ou seja, maior acúmulo de biomassa no tratamento sem herbicida (testemunha), seguido dos manejos com 18,75 e 37,50 $\mathrm{g} \mathrm{ha}^{-1}$ de fluazifop-p-butil.

Também para número de colmos (Figura 3-A), comprimento dos colmos (Figura 3-B) e razão de peso dos colmos (Figura 3-C) verificouse interação entre manejos e épocas de coleta. $\mathrm{O}$ número de colmos, que reflete o perfilhamento da forrageira, apresentou comportamento inverso ao do acúmulo de biomassa seca. Nas plantas sob o efeito do herbicida, observou-se, aos 14 dias da aplicação do fluazifop-p-butil (42 DAE), acentuado perfilhamento. Verificou-se que doses reduzidas deste herbicida promoveram a quebra da dominância apical de $B$. brizantha, ocorrendo intensa formação de novos perfilhos, como pode ser melhor visualizado na Figura 4. Segundo Luo et al. (2001), é possível que, além de inibir a enzima ACCase, os herbicidas derivados do grupo aril oxifenoxi-propionatos possuam também efeito antiauxina. Esses autores verificaram que a elongação do coleóptilo de Avena sativa, induzida pelo 2,4-D ou ácido indol acético (AIA), foi inibida pelos herbicidas fluazifop-p-butil e sethoxydim.

Nas avaliações realizadas a partir de 56 DAE, o número de colmos tendeu a se estabilizar. De acordo com Gomide (1997), o número de perfilhos cresce até certa idade, para posteriormente estabilizar-se, em decorrência da instalação do processo de senescência e morte de perfilhos.

O menor comprimento dos colmos de $B$. brizantha tratada com fluazifop-p-butil em relação à testemunha (Figura 3-B) e a menor altura das plantas (Figura 4) confirmam a quebra da dominância apical, promovendo efeito de poda de B. brizantha.

Planta Daninha, Viçosa-MG, v. 23, n. 1, p. 85-91, 2005
A razão de biomassa dos colmos (biomassa seca retida nos colmos por biomassa acumulada na planta toda) apresentada na Figura 3-C, a partir dos 14 dias da aplicação,
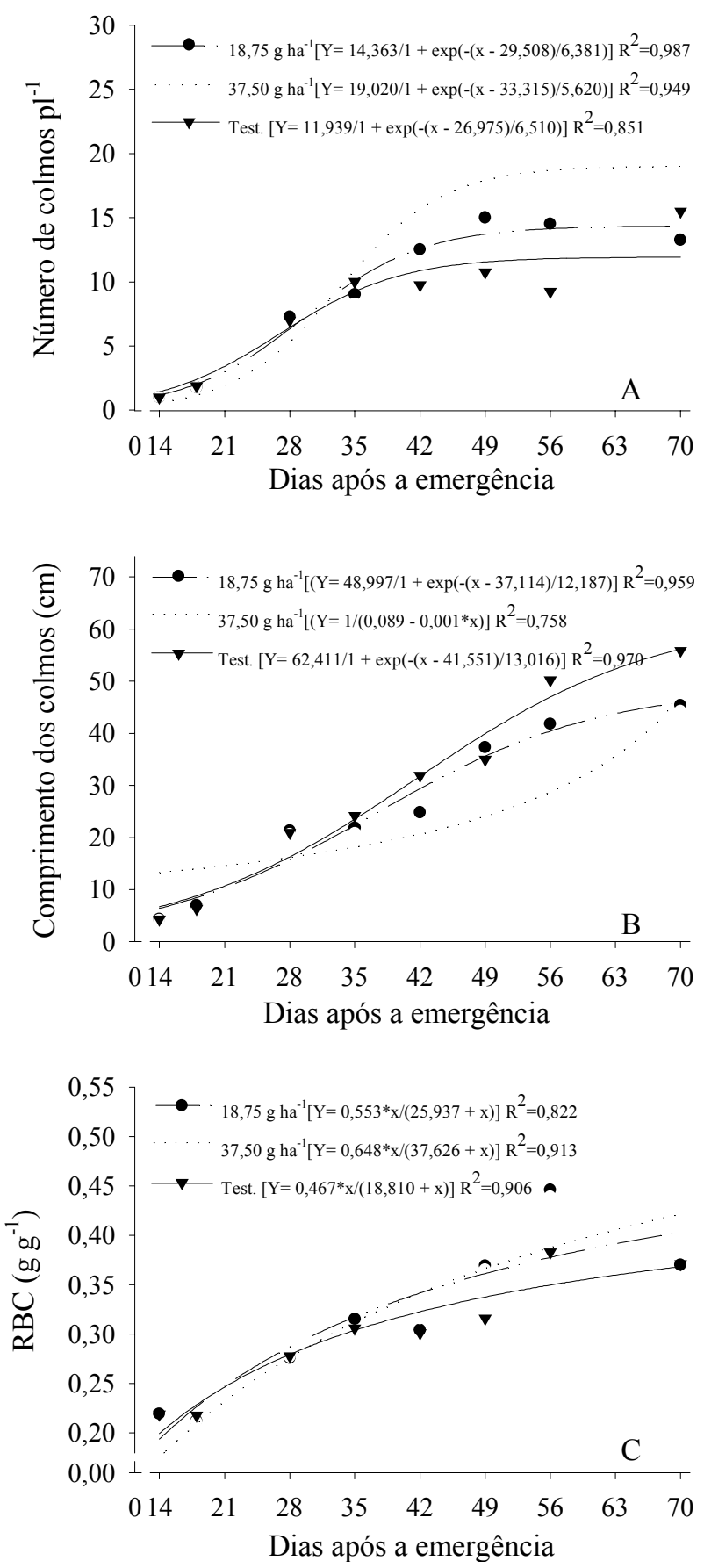

Figura 3 - Número de colmos (A), comprimento dos colmos (B) e razão de biomassa dos colmos - RBC (C) de plantas de $B$. brizantha, em função da época de avaliação e de doses de fluazifop-p-butil. 
foi maior para as plantas sob efeito do fluazifopp-butil, as quais apresentaram maior participação dos colmos na biomassa total da planta em relação à testemunha, demonstrando o efeito do intenso perfilhamento proporcionado pelo fluazifop-p-butil. No decorrer do desenvolvimento das plantas, verificou-se aumento na participação dos colmos em todos os manejos. Para a razão de biomassa das folhas não foi observada interação entre manejos e épocas de coleta. Contudo, o efeito da época de coleta foi significativo, constatando-se redução da participação das folhas na biomassa total com o desenvolvimento das plantas. Resultados semelhantes a esses foram observados por Portes et al. (2000), os quais verificaram gradual redução da relação folha/colmo com o desenvolvimento das plantas de $B$. brizantha.

Também a área foliar das plantas de $B$. brizantha foi reduzida sob o efeito do herbicida (Figura 5-A), sendo essa redução mais pronunciada na maior dose. Todavia, verificou-se incremento na área foliar em todos os manejos no decorrer do desenvolvimento das plantas.
A área foliar específica (Figura 5-B) relaciona a superfície e o peso da folha, representando a espessura desta. Observouse que a área foliar específica foi reduzida com o decorrer do ciclo para todos os manejos. No entanto, o decréscimo foi maior na testemunha, indicando que as plantas que não estavam sob efeito do fluazifop-p-butil apresentaram folhas mais espessas. Essa tendência pode ser explicada pelo perfilhamento de $B$. brizantha induzido pelo herbicida que promoveu intensa formação de folhas novas, as quais são mais finas.

Quanto à razão de área foliar (Figura 5-C), constatou-se interação entre manejos e épocas de coleta das plantas. A razão de área foliar (área foliar em metro quadrado que está sendo usada pela planta para produzir $1 \mathrm{~g}$ de biomassa seca) foi maior em plantas tratadas com fluazifop-p-butil. Considerando que a razão de área foliar é composta pela razão entre peso da folha e área foliar específica e que não houve diferença entre os manejos para o primeiro componente, conclui-se que a variação na razão de área foliar foi influenciada pela

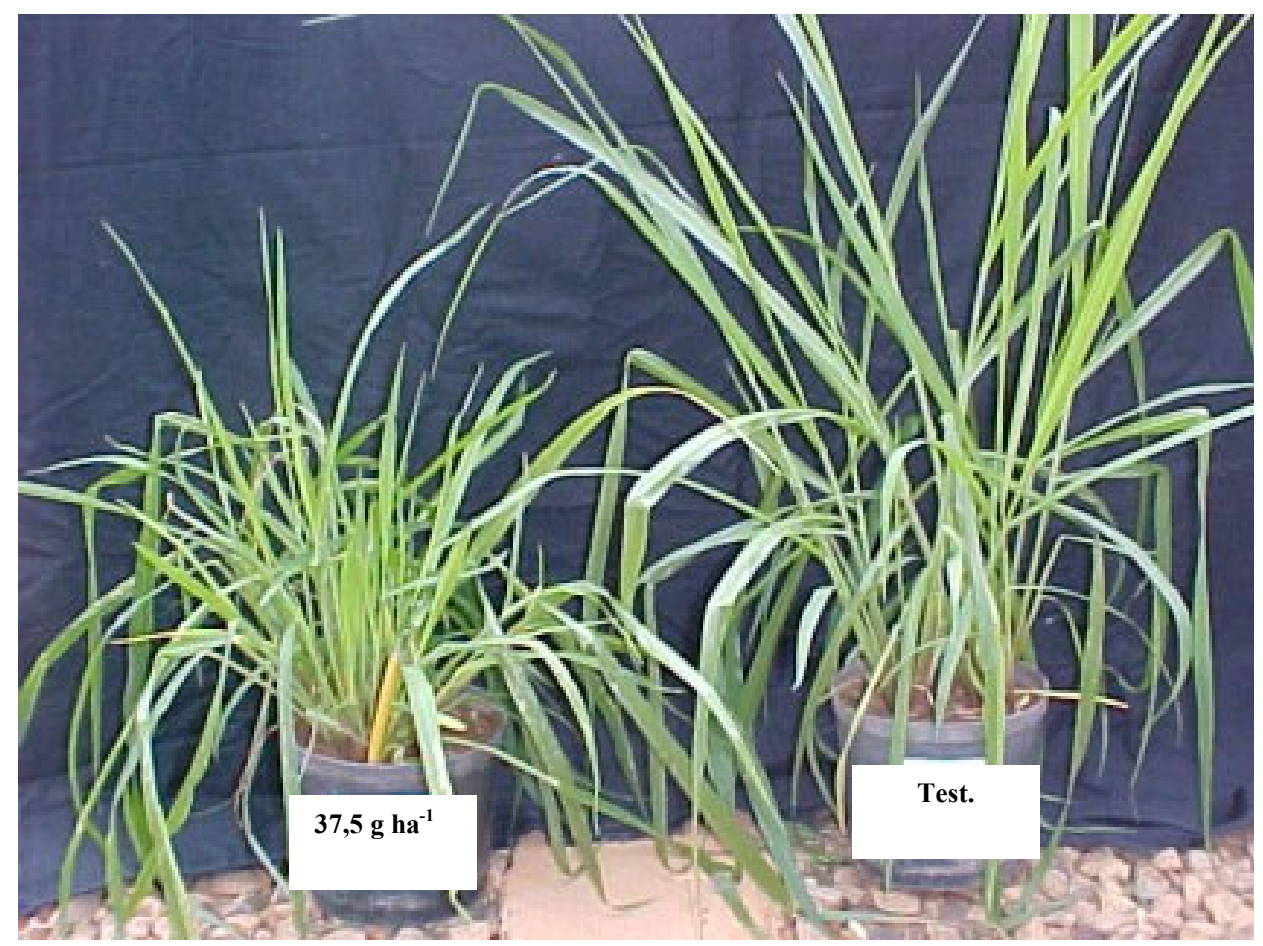

Figura 4 - B. brizantha submetida a $37,5 \mathrm{~g} \mathrm{ha}^{-1}$ de fluazifop-p-butil, aplicado aos 28 DAE, e testemunha sem herbicida, aos 42 DAE. 
área foliar específica. Observou-se que esse componente declinou com o crescimento das plantas em todos os manejos. Segundo Benincasa (2003), com o crescimento, aumenta a interferência de folhas superiores sobre as inferiores (auto-sombreamento), e a tendência é de a área foliar útil diminuir.
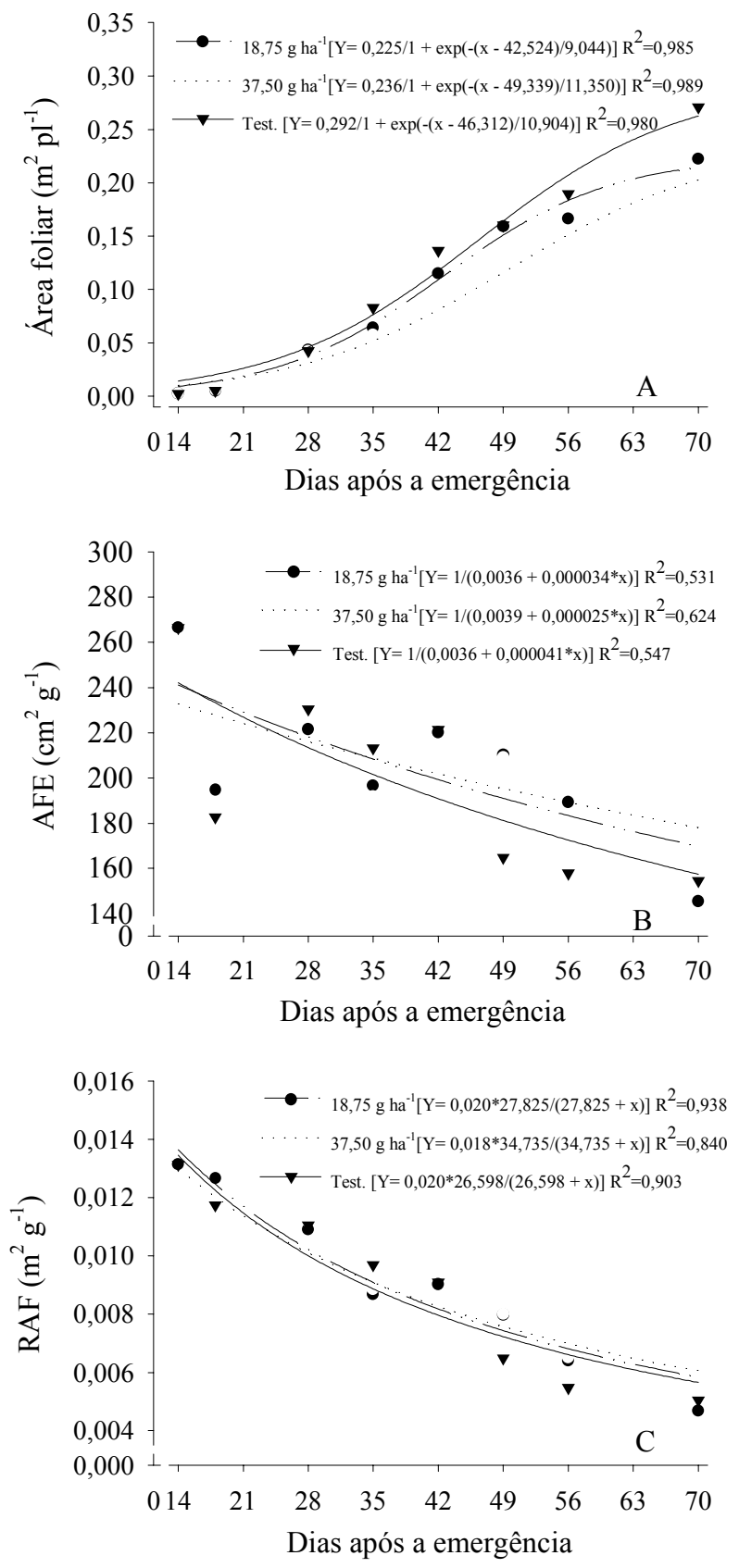

Figura 5 - Área foliar (A), área foliar específica - AFE (B) e razão de área foliar - RAF (C) de plantas de B. brizantha, em função da época de avaliação e de doses do fluazifop-pbutil.

Planta Daninha, Viçosa-MG, v. 23, n. 1, p. 85-91, 2005
Para taxa de crescimento absoluto (Figura 6-A), taxa de crescimento relativo (Figura 6-B) e taxa assimilatória liquida (Figura 6-C), houve interação entre épocas de coleta e manejos.

A taxa de crescimento absoluto expressa a velocidade média de crescimento ao longo
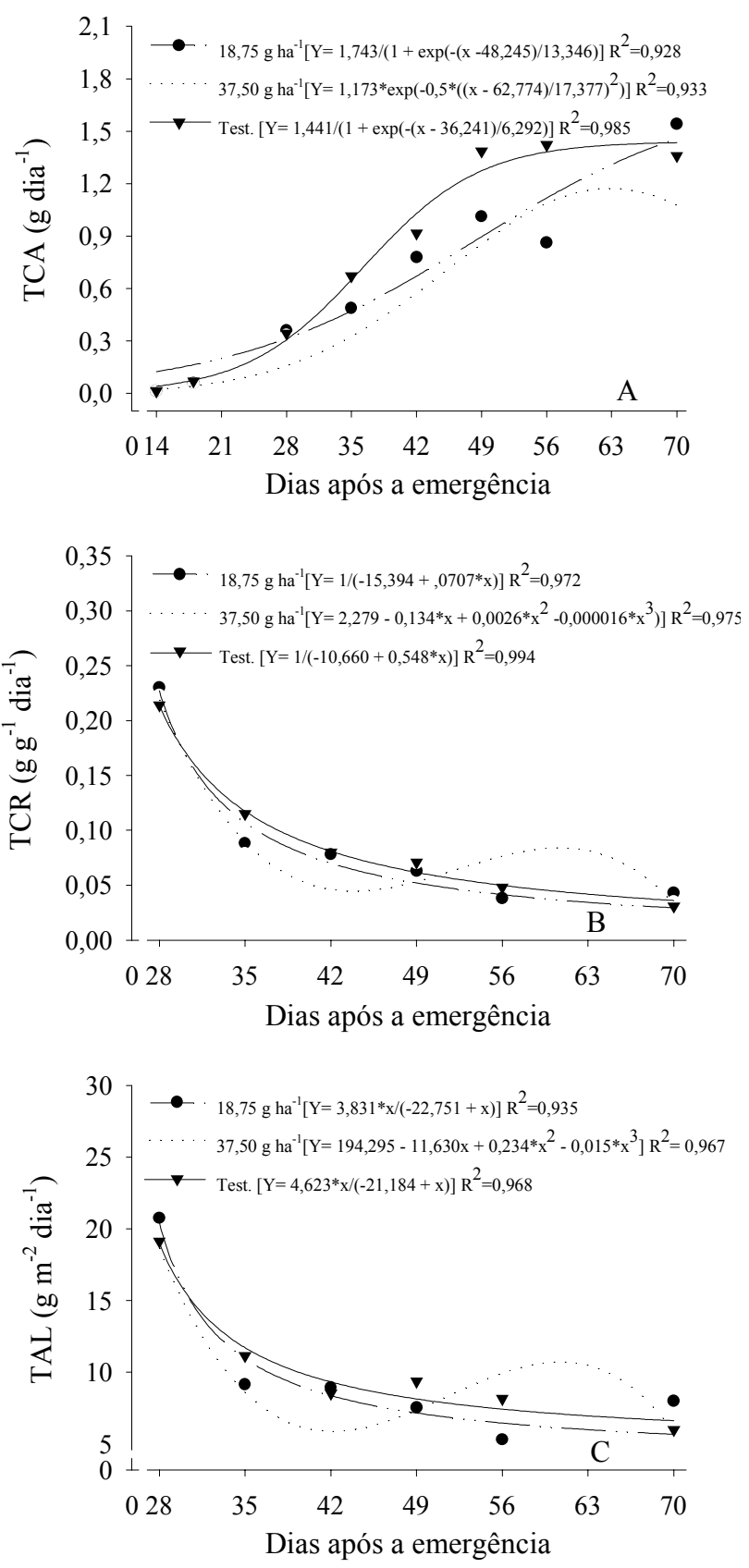

Figura 6 - Taxa de crescimento absoluto - TCA (A), taxa de crescimento relativo - TCR (B) e taxa assimilatória líquida - TAL (C) de plantas de B. brizantha, em função da época de avaliação e de doses de fluazifop-p-butil. 
do período de observação. No período de 35 a $70 \mathrm{DAE}$, a taxa de crescimento absoluto média (dados observados) foi de 0,768, 0,936 e 1,153 g por dia para os tratamentos com 37,50 e $18,75 \mathrm{~g}$ de fluazifop-p-butil e a testemunha sem herbicida, respectivamente, ou seja, constatou-se redução de 0,385 g ao dia de biomassa das plantas submetidas à maior dose do herbicida, comparada à testemunha. Essa tendência pode ser visualizada na Figura 6-A.

A taxa de crescimento relativo é o aumento em gramas de biomassa seca por unidade de material presente num periodo de observação; assim, qualquer incremento ao longo de determinado período estará diretamente relacionado à biomassa alcançada ao longo de um intervalo anterior. Observa-se (Figura 6-B) que a taxa de crescimento relativo da testemunha foi sempre maior que a do tratamento submetido a $18,75 \mathrm{~g}^{-1} \mathrm{a}^{-1}$ do fluazifop-p-butil. Quanto às plantas de $B$. brizantha tratadas com $37,50 \mathrm{~g} \mathrm{ha}^{-1}$ do herbicida, elas apresentaram taxa de crescimento inferior à da testemunha até os 42 DAE. Entretanto, observou-se incremento na taxa de crescimento após esse período, em virtude do intenso perfilhamento. A mesma tendência foi observada para a taxa assimilatória líquida (Figura 6-C), que é um componente da taxa de crescimento relativo, o que explica a mesma tendência.

Como conclusões finais deste trabalho, pode-se afirmar que doses reduzidas do fluazifop-p-butil promoveram a quebra da dominância apical de $B$. brizantha, induzindo acentuado perfilhamento desta espécie; além disso, ocorreu aumento da participação dos colmos na biomassa seca total e redução do comprimento dos colmos em relação à testemunha. As plantas submetidas ao herbicida apresentaram folhas mais finas, com menor área foliar. O tratamento das plantas de $B$. brizantha com fluazifop-p-butil reduziu a taxa de crescimento absoluto, mas esta não foi paralisada, demonstrando a possibilidade da utilização de doses reduzidas desse herbicida na redução do crescimento de $B$. brizantha sem, contudo, causar danos letais à forrageira.

\section{LITERATURA CITADA}

BENINCASA, M. M. P. Análise de crescimento de plantas, noções básicas. 2 ed. Jaboticabal: FUNEP, 2003. $41 \mathrm{p}$.
DIAS-FILHO, M. B. Growth and biomass allocation of the $\mathrm{C} 4$ grasses Brachiaria brizantha and B. humidicola under shade. Pesq. Agropec. Bras., v. 35, n. 12, p. 2335-2341, 2000 .

DIAS-FILHO, M. B.; CARVALHO, C. J. R. Physiological and morphological responses of Brachiaria spp. to flooding. Pesq. Agropec. Bras., v. 35, n. 10, p. 1959-1966, 2000.

DUARTE, J. M. et al. Producción de maíz (Zea mays L.), soya (Glycine max L.) y caupi (Vigna unguiculata (L.) Walp) sembrados en asociación con gramíneas en el trópico húmedo. Past. Trop., v. 17, n. 2, p. 12-19, 1995

GOMIDE, J. A. Morfogênese e análise de crescimento de gramíneas tropicais. In: SIMPÓSIO INTERNACIONAL SOBRE PRODUÇÃO ANIMAL EM PASTEJO, 1., 1997, Viçosa. Palestras... Viçosa: José Alberto Gomide, 1997. p. 411-429

JAKELAITIS, A. et al. Controle de plantas daninhas, crescimento e produção de milho e Brachiaria brizantha cultivados em consórcio. B. Inf. SBCPD, v. 10, p. 231-232, 2004 (Suplemento).

KONISHI, T. et al. Y. Acetyl-CoA carboxylase in higher plants: most plants other than gramineae have both the prokaryotic and the eucaryotic forms of this enzyme. Plant Cell Physiol., v. 37, p. 117-122, 1996.

LIMA, P. R. F.; MACHADO-NETO, J. G. Otimização da aplicação de fluazifop-p-butil em pós-emergência na cultura da soja (Glycine $\max$ ). Planta Daninha, v. 19, n. 1, p. 8595,2001

LUO, X.; MATSUMOTO, H.; USUI, K. Comparison of physiological effects of fluazifop-p-butyl and sethoxydim on oat (Avena sativa L.). Weed Biol. Manag., v. 1, n. 2, p. 120-125, 2001.

PEREZ, H. E.; PEZO, D. A.; ARZE, J. Growth of Brachiaria brizantha and Brachiaria dictyoneura associated with soybean (Glycine max L.). Pasturas Trop., v. 15, n. 1, p. 2-9, 1993.

PORTES, T. A. et al. Análise do crescimento de uma cultivar de braquiária em cultivo solteiro e consorciado com cereais. Pesq. Agropec. Bras., v. 35, n. 7, p. 1349-1358, 2000.

SILVA, A.C. et al. Efeitos de doses reduzidas de fluazifopp-butil no consórcio entre soja e Brachiaria brizantha. Planta Daninha, v. 22, n. 3, p. 429-435, 2004.

THILL, D. C.; WELLER, S. C. Lipid biosyntesis inhibitors. In: Herbicide action course. Wes Lafayetty: Purdue University, 1995. 787 p.

TIMOSSI, P. C.; DURIGAN, J. C. Doses reduzidas de fluazifop-p-butil + fomesafen no controle de plantas daninhas na cultura da soja. Planta Daninha, v. 20, n. 3, p. 439-447, 2002.

Planta Daninha, Viçosa-MG, v. 23, n. 1, p. 85-91, 2005 